\title{
Influence of Salt Stress on Jojoba Seedlings under Net Shad House Conditions
}

\author{
Belal, A. H. "; Eman I. El-Sarag ; ; k. E. Al-Kahlot ${ }^{* *}$ and Dalia A. Soliman* \\ *Fac., Env. Agri. Sci. Suez Canal University \\ Fac. of Sci. Islamic University, Gaza
}

Received: 16/10/2014

\begin{abstract}
This study has been carried out at the Faculty of Environmental Agricultural Science (FEAS), Al-Arish Suez Canal University (SCU) during the successive growing season 2012/2013. The third experiment has been done at the shad net house of the experimental crop farm using jojoba seedlings at one year old, which growing in pots. Seedlings have been irrigated four times weekly in different four treatments of saline water concentrations 2000, 4000, 6000 and $8000 \mathrm{ppm}$, beside the control (tap water). It was observed that vegetative characters of the plants were significantly decreased with increasing saline water irrigation levels .The maximum values of number of branches, root length and number of secondary roots .were resulted with low saline water irrigation level (tap water), followed by $2000,4000,6000$ and $8000 \mathrm{ppm}$ which gave the minimum values in this respect. The obtained results cleared that the concentration of nitrogen, phosphorus and potassium decreased in plant tissue with increasing salinity concentration level.
\end{abstract}

Keywords: Saline water Stress, Jojoba Seedlings, Net Shad House, Vegetative characters, Leaf chemical composition.

\section{INTRODOCTION}

Jojoba (ho-ho-ba) plant (Simmondsia chinensis Link' Schneider) is a name that is becoming increasingly common. It is a native of the arid zones of America and Mexico, (Saeed et al., 2005 a, b). Jojoba is a woody evergreen shrub that is communally $2-3$ feet high and easily recognized by its thick, leathery, bluish green leaves and dark brown nut like fruit.Jojoba seeds contain about $50 \%$ oil by weight (Johnson and Hinman, 1980). In addition, the oil has thermal stability and high smoke, flash, and fire point. The decomposition point is $315^{\circ} \mathrm{C}$ and the freezing point is also high.Jojoba oil is very similar to that obtained from sperm whole. This plant can grow well under the arid area Meanwhile, water regime and salt tolerance, as well as, most other cultural practices of this plant have not been investigated under the Egyptian conditions. Land reclamation projects in Egypt needs crops which tolerate water and salt stress. (Naqvi et al., 1988 and Wisniak, 1987). The initial growth reduction in saline stressed plants is due to the osmotic effect of the salts surrounding the roots Munns,(2002).The salinity characteristics such as dry matter, and leaf area and plant height decreased with increasing salinity in addition to the chemical component decreased significantly with increasing of salinity levels Kamrani et al., (2013). The suppression of shoot and root grown under salt stress may either be due to osmotic reduction in water availability or to excessive accumulation of ions, known as specific ion effect (Ali et al, 2012). Hussain et al., 2011 studded that less number of branches might be due to salinity concentration in the root medium that effected significantly this trait. Nasim et al., 2008 recorded a reduction percentage of $47 \%$ in number of branches/plant at the higher salinity level 930 $\mathrm{ds} / \mathrm{m}$ in a solution culture experiment on eucalypts. This work aimed to investigate the effect of salt stress on vegetative growth, chemical composition of Jojoba plant.

\section{MATERIALS AND METHODS}

This study was carried out at Faculty of Environmental Agricultural Sciences, El-Arish, Suez
Canal University in the experimental shade net house during three successive months of 2012/2013 growing season. The plant materials of experiments were obtained from El-Sheikh Zewaid Experimental Research, North Sinai Governorate, Desert Research Center. Seedling (one year old) have been irrigated four times weekly in different saline water concentration $(0$, 2000, 4000, 6000 and $8000 \mathrm{ppm}$ ), beside the control (tap water). Seedlings were cultured within 3 replications ( 5 plant in every replication) and the height of them was $20 \mathrm{~cm}$.

\section{Recorded data}

\section{A. Morphological characters}

The following data were recorded every month for seedling of ex vitro experiment: (Number of branches / plant - Number of leaf / plant - Number of roots/plant Root length).

\section{B. Chemical analysis}

In these investigation chemical components were analyzed 60 and 90 days after irrigation with saline water.

\section{B.1.Nitrogen determination}

The total nitrogen was determined by Nesler method described by Bremner and Mulvanc (1982).

\section{B.2. Phosphorus determination}

The $\mathrm{P}$ content was measured spectrophotometrically after digestion of plant material in a sulphuric acid and perchloric acid by the M. blue method (Jackson, 1973).

\section{B.3. Potassium determination}

Potassium was determined using flame photometer according to Chapman and Pralt, 1961. The results were calculated from a standard curve of potassium dihydrogen phosphate.

\section{Statistical analysis}

The obtained data were subjected to the analysis of variance via randomized complete design according to the method outlined by Steel and Torrie, 1980. Least significant difference (LSD) method was used to mean separation at $\mathrm{P} \leq 0.05$ level. Computations were fulfilled conformably with PLABSTAT computer program package. 


\section{RESULTS AND DISCSSION}

\section{Effect of salt stress on Jojoba seedling:}

Growth parameters:

Data presented in Table 1 show the effect of salt stress on growth parameters (number branches/plant, no. of leaves, root length, number of secondary root)

Generally, it could be concluded that, all the studied growth parameters were negatively affected with salt stress and the decrements were paralleled with the increase of salt concentration. In all the studied growth parameters differences between treatments were significant. Jojoba seedlings irrigated with 8000 ppm saline water concentration had the extremist reduction in growth compared to the other concentrations (6000ppm, 4000ppm and 2000ppm). Similar results were obtained by Munns,(2002); Amin, et al., (2002) ; Atta (2002) ; Maklad (2003 ; Saeed et al., (2005 a,b) ;Nasim et al. ,2008) ; Hussain et al 2011 ; Ali et al.,
(2012) and Kamrani et al., (2013) .They mentioned that, the depressive effect of salinity on plant growth may be due to the increase in the osmotic potential of the soil which results in a reduction in the availability of water to the plant. In addition, the toxic effect of some ions which make disturbance in the normal metabolism of the plant.

\section{Leaf chemical composition on dry leaves:-}

Data illustrate in Table 2 reflect that increasing salinity concentration levels decreased chemical composition parameters (nitrogen, phosphorus and potassium percentage \%). All the studies were observed that chemical composition parameters were negatively affected with salt stress significantly.

Jojoba plants irrigated with 8000 ppm saline water concentration had the extremist reduction in chemical composition compared to the other concentrations (6000 ppm, 4000 ppm and 2000 ppm).

Table (1): Effect of salt stress on vegetative growth parameters of jojoba plants, one year old at three successive months of 2012/2013 growing season under shad net house conditions.

\begin{tabular}{|c|c|c|c|c|c|c|c|c|c|}
\hline \multirow{2}{*}{ Traits } & \multirow{2}{*}{ Month } & \multicolumn{5}{|c|}{ Salinity level (ppm) } & \multicolumn{3}{|c|}{ L.S.D.at 5\% } \\
\hline & & Control & 2000 & 4000 & 6000 & 8000 & Month & Salinity & MxS \\
\hline \multirow{4}{*}{$\begin{array}{c}\text { No. of } \\
\text { branches } \\
\text { /plant }\end{array}$} & 1 & 11.20 & 10.00 & 7.60 & 6.80 & 6.20 & \multirow{4}{*}{$2.18^{*}$} & \multirow{4}{*}{$1.18 *$} & \multirow{4}{*}{$2.41 *$} \\
\hline & 2 & 11.40 & 8.80 & 7.40 & 6.60 & 5.60 & & & \\
\hline & 3 & 12.80 & 7.60 & 7.20 & 6.40 & 5.40 & & & \\
\hline & Mean & 11.80 & 8.80 & 7.40 & 6.60 & 5.73 & & & \\
\hline \multirow{4}{*}{$\begin{array}{c}\text { No. of } \\
\text { leaves/plant }\end{array}$} & 1 & 33.60 & 33.75 & 31.80 & 29.20 & 25.80 & \multirow{4}{*}{$2.29 *$} & \multirow{4}{*}{$2.91 *$} & \multirow{4}{*}{$2.94 *$} \\
\hline & 2 & 37.00 & 33.60 & 31.50 & 27.75 & 24.75 & & & \\
\hline & 3 & 38.25 & 32.40 & 29.00 & 25.00 & 22.80 & & & \\
\hline & Mean & 36.28 & 33.25 & 30.77 & 27.32 & 24.45 & & & \\
\hline \multirow{4}{*}{$\begin{array}{l}\text { Root length } \\
\quad \text { (cm) }\end{array}$} & 1 & 20.20 & 19.50 & 18.00 & 15.10 & 14.90 & \multirow{4}{*}{$2.44 *$} & \multirow{4}{*}{$2.04 *$} & \multirow{4}{*}{$2.93 *$} \\
\hline & 2 & 21.00 & 18.00 & 15.50 & 12.75 & 9.80 & & & \\
\hline & 3 & 21.60 & 16.00 & 14.80 & 11.60 & 9.75 & & & \\
\hline & Mean & 20.93 & 17.83 & 16.10 & 13.15 & 11.48 & & & \\
\hline \multirow{4}{*}{$\begin{array}{l}\text { Number of } \\
\text { secondary } \\
\text { roots }\end{array}$} & 1 & 12.20 & 10.60 & 8.40 & 6.50 & 5.20 & \multirow{4}{*}{$1.39 *$} & \multirow{4}{*}{$1.16^{*}$} & \multirow{4}{*}{$1.66^{*}$} \\
\hline & 2 & 12.80 & 9.50 & 7.25 & 6.40 & 5.00 & & & \\
\hline & 3 & 13.20 & 9.40 & 6.80 & 6.40 & 3.75 & & & \\
\hline & Mean & 12.73 & 9.83 & 7.48 & 6.43 & 4.65 & & & \\
\hline
\end{tabular}

Table (2): Effect of salt stress on some chemical component parameters of jojoba seedlings, one year old at 60 or 90 days of 2012/2013 growing season under shad net house conditions.

\begin{tabular}{|c|c|c|c|c|c|c|c|c|}
\hline \multirow{2}{*}{ Traits } & \multirow{2}{*}{ Records } & \multicolumn{4}{|c|}{ Salinity (ppm) } & \multicolumn{3}{|c|}{ L.S.D.at 5\% } \\
\hline & & 2000 & 4000 & 6000 & 8000 & Records & Salinity & $\mathbf{R x S}$ \\
\hline \multirow{3}{*}{$\begin{array}{c}\text { Nitrogen } \\
\text { percentage } \%\end{array}$} & 60 & 4.18 & 3.39 & 3.45 & 3.02 & \multirow{3}{*}{$0.21 *$} & \multirow{3}{*}{$0.72 *$} & \multirow{3}{*}{$0.80 *$} \\
\hline & 90 & 4.38 & 3.05 & 2.08 & 1.87 & & & \\
\hline & Mean & 4.28 & 3.22 & 2.76 & 2.44 & & & \\
\hline \multirow{3}{*}{$\begin{array}{c}\text { Phosphor } \\
\text { percentage } \%\end{array}$} & 60 & 1.40 & 1.40 & 1.30 & 1.20 & \multirow{3}{*}{ Ns } & \multirow{3}{*}{$0.37 *$} & \multirow{3}{*}{ Ns } \\
\hline & 90 & 1.40 & 1.30 & 1.30 & 1.30 & & & \\
\hline & Mean & 1.40 & 1.35 & 1.30 & 1.25 & & & \\
\hline \multirow{3}{*}{$\begin{array}{c}\text { Potassium } \\
\text { percentage } \%\end{array}$} & 60 & 2.79 & 2.61 & 1.33 & 1.26 & \multirow{3}{*}{ Ns } & \multirow{3}{*}{$0.19 *$} & \multirow{3}{*}{$0.60^{*}$} \\
\hline & 90 & 2.70 & 2.22 & 1.80 & 1.35 & & & \\
\hline & Mean & 2.74 & 2.41 & 1.56 & 1.30 & & & \\
\hline
\end{tabular}


Similar results were obtained by Saeed et al., 2005c, Ali et al., 2012.The reduction of chemical component due to the reduction of nitrification rate of ammonia which resulted from the large direct toxic effects of Cl- and the total amount of salt on the activity of nitrifying bacteria (Stark and Firestone, 1995). Kochian (2000) suggests that the reduction of the availability of phosphorus in saline soils is the result of the activity of ions- antagonists, which can reduce the activity of phosphate and phosphate transporters of both high and low affinity, which are necessary for the uptake of phosphorus. It has been shown that increased concentrations of $\mathrm{Na}+$ block channel protein used for the uptake of $\mathrm{K}+, \mathrm{AKT} 1$, and in this way reduce the uptake of $\mathrm{K}+$. Inhibitory effect of $\mathrm{Na}+$ on transport of $\mathrm{K}+$ through channels in the membranes is probably more important in the phase of uptake of $\mathrm{K}+$ from the soil solution than in the phase of $\mathrm{K}+$ transport to the xylem (Qi and Spadling, 2004).

\section{REFERENCE}

Ali, E.F.; Hassan, F. As. and EL-zahrany, O.M (2012). Planting of jojoba for oil production under salt and water stress in Taif region. Aust-J. Basi and Appi. Sci, 6 (13). 358-371.

Amin, K.I.A.; H.A. Ragheb; H.A. Abdel-Galil, and Y.S. Ali (2002). Differential tolerance of seedlings of some pomegranate cultivars to salinity. Assiut. J. Agric. Sci., 33, (2).

Atta, A.A. (2002). Studies on growth of olive plants under salt stress. Ph.D. Thesis, Fac. Agric., Cairo Univ., Egypt.

Bremner, J. M. and C.M. Mulvanc, (1982).Total nitrogen analysis, methods of soil. In (Page, A.L; R.H Miller and D. R. Keeny (Eds).Part 2 Amer .Soc. Agron. Madison. WI-W. S. Ap (595-624).

Chapman, H.D. and Pralt, P. E. (1961). Methods of Soil, Plants and Water Analysis. University of California, Division of Agricultural Sciences.

Hussain,G.; Bashir, M.A. and Ahmad, M. (2011). Brackish water impact on growth of Jojoba (Simmondsia chinensis). J. Agric. Res., 49(4).

Jackson, M.L. (1973). Soil Chemical Analysis. Prentic Hall. of India Private Limited, New Delhi.

Johnson, J.D. and C.W. Hinman (1980). Jojoba for new land. Science 208: 460.

Kamrani, M. H.; Hasseinniya H. and Chegen, A.R. (2013). Effect of salinity on the growth characteristic of Canola (Brassica napus L.) Tech.
J. of Engin and App. Scien. TJEAS J. - 3. (18)/ $2327-2333$.

Kochian, L.V. (2000). Molecular physiology of mineral nutrient acquisition, transport and utilization. In: Biochemistry and Molecular Biology of Plants. B.B. Buchan, W. Gruissen, R.L. Jones (Eds.) American Society of Plant Physiology, Rockville, EUA, pp. 1204-1249.

Munns, R. (2002). Comparative physiology of salt and water stress, plant Cell Env., 25: 239-250.

Maklad, (2003). Salt tolerance of mango and olive plants in response to mycorrhizae inoculation. M.Sc. Thesis Fac. Agric. Moshtohor, Zagazig Univ., Egypt.

Naqvi, H.H.; G. Goldstein and I.P. Ting (1988). A new multipurpose industrial crop for arid environments. El-Guayulero, 10 (3, 4). 8-14.

Nasim, M.; Saqib, M.; Aziz,T.; Nawaz, S.; Akhtar, J.; Anwar-ul-Haq, M. and Sahi,S.T. (2008). Changes in growth and ionic composition of Eucalyptus camaldulensis under salinity and waterlogging stress; a lysimeter study. Soil \& Environ. 27 (1). 93-98.

Qi, Z. and Spalding, E.P. (2004). Protection of plasma membrane $\mathrm{K}+$ transport by the salt overly sensitive $\mathrm{Na}+-\mathrm{H}+$ antiporter during salinity stress. Plant Physiology, 136, 2548- 2555.

Saeed, W.T.; A.M. El-Khashab and S.A. Abou Taleb (2005a). Physiological studies on Jojoba plant. AResponse of Jojoba seedlings to NPK fertilization and $\mathrm{GA}_{3}$ foliar application. Minufiya J. Agric. Res., 29 (6). 1367-1370.

Saeed, W.T.; A.M. El-Khashab and S.A. Abou Taleb (2005b). Physiological studies on Jojoba plant. Effect of some ecology stress on Jojoba seedlings. Minufiya J. Agric. Res.

Saeed, W. T.; EL-Kashab, M. and S.A. Abou Taleb, (2005). Physiologyical studies on jojoba seedling, Bulletin of Faculty of Agri, Cairo University; 1, 121-141.

Stark, J.M. and Firestone, M.K. (1995). Mechanisms for soil moisture effects on activity of nitrifying bacteria. Applied and Environmental Microbiology, 61, 218-221.

Steel, R. G.D. and Torrie, T.H. (1980). Principles and procedures of statistics Mc Graw-Hill. International Book Combany $3^{\text {rd }}$ Ed. London, p. 633.

Wisnaik, J. (1987). The chemistry and technology of Jojoba oil. Ame. Oil Chem. Soc. Champan, Italy. 


\section{تأثير الإجهاد الملحى على شتلاث الجوجوبا تحث ظروف صوبة الظل

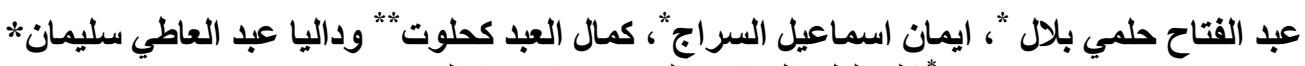

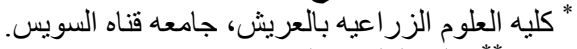

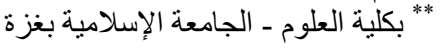

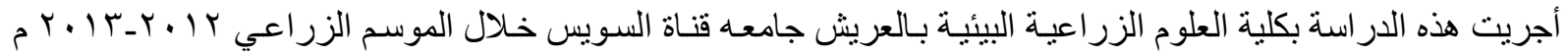

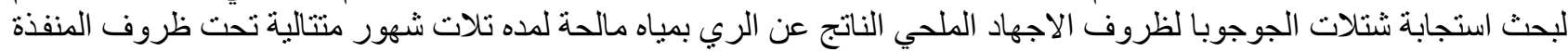

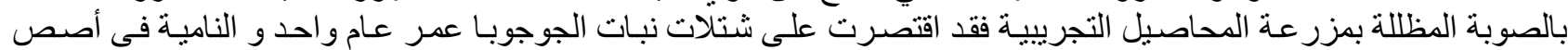

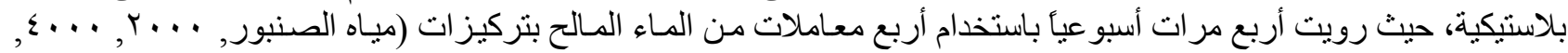

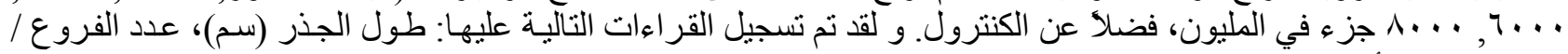

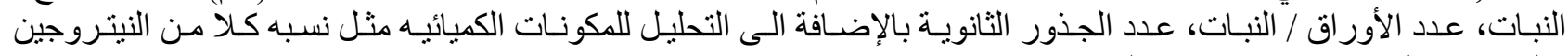

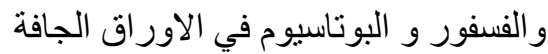

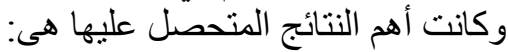

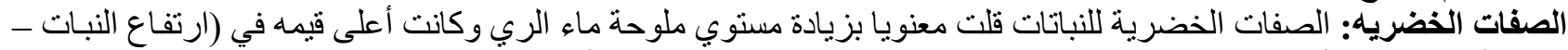

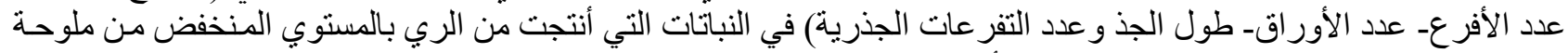

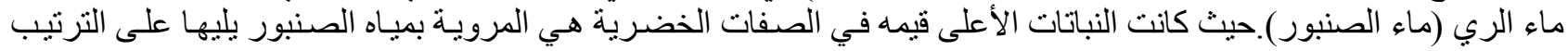

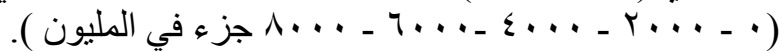

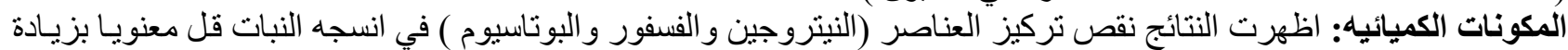

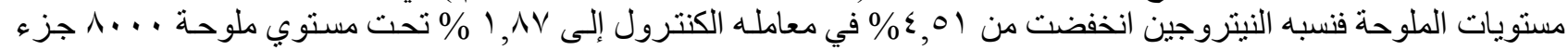

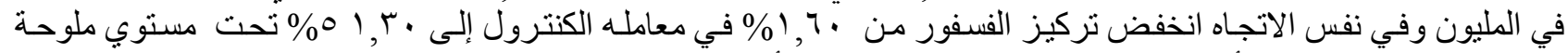

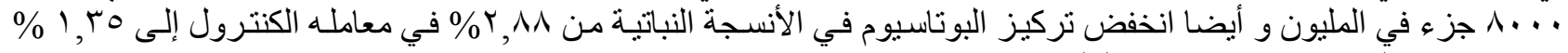

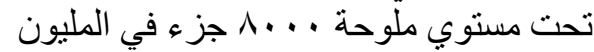

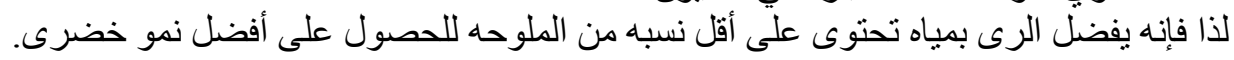

